\title{
Non-isotopic detection of in situ nucleic acid in cervix: an updated protocol
}

\author{
J BURNS, A K GRAHAM, J O'D MCGEE University of Oxford, Nuffield Department of Pathology, \\ John Radcliffe Hospital, Oxford
}

SUMMARY Recently, sensitive non-isotopic in situ hybridisation (NISH) methodology for the detection of human DNA and human papilloma virus (HPV) DNA in archival paraffin blocks of cervix was described. An amended protocol, now used in this laboratory for detection of these genes by NISH is presented. The amendments include the following: protease digestion at $37^{\circ} \mathrm{C}$; tissue dehydration in air rather than ethanol; stringency washing in formamide solution; blocking nonspecific binding of avidin alkaline phosphatase with a modified buffer; and increasing the concentration of avidin alkaline phosphatase for detecting low abundance DNA.

These changes simplify and increase the sensitivity of the protocol such that " $Y$ " chromosome repeats are visualised in almost all female cells.

Visualisation of pHY2.1 autosomal repeat sequences has been used as a built-in sensitivity control for detection of human papillomavirus (HPV) nucleic acid in formalin fixed paraffin wax embedded cervical biopsy specimens.' Using archival paraffin wax embedded material from the 1970 s, we recently found that the pHY2.1 signal varies in consistency and intensity. In this paper we report modifications to the earlier protocol' ${ }^{1}$ which increases the consistency and intensity of the pHY2.1 signal in this type of biopsy specimen; by extrapolation and experiment the HPV signal detected by in situ hybridisation is also increased.

\section{Material and methods}

1 Mount formalin fixed paraffin wax sections on glass multispot slides treated with aminopropyltriethoxysilane, dry at $37^{\circ} \mathrm{C}$ for 30 minutes, and bake sequentially at $75^{\circ} \mathrm{C}$ for 60 minutes and overnight at $60^{\circ} \mathrm{C}$. In urgent cases biopsy specimens can be satisfactorily probed after the $75^{\circ} \mathrm{C}$ baking step. Sections can be stored indefinitely at $22^{\circ} \mathrm{C}$.

2 Dewax sections by heating at $75^{\circ} \mathrm{C}(15$ minutes $)$ and transferring immediately to xylene at $22^{\circ} \mathrm{C}$, changing xylene (10 minutes twice). Wash in $99 \%$ ethanol (10 minutes twice), wash in running tap water (five minutes), and preheat sections in distilled water in a coplin jar, kept at $37^{\circ} \mathrm{C}$ in a high water line water bath. Viral and human nucleic acids are unmasked by

Accepted for publication 9 February 1988 exposing sections to pepsin at $5 \mathrm{mg} / \mathrm{ml}$ (ca 2500 units/ $\mathrm{mg}$ protein (Boehringer Mannheim, UK)) in $0.2 \mathrm{M}$ hydrochloric acid for 15 minutes at $37^{\circ} \mathrm{C}$. Pepsin, $500 \mathrm{mg}$, is dissolved by gentle agitation in $96 \mathrm{ml}$ distilled water, preheated at $37^{\circ} \mathrm{C}$, and $4 \mathrm{ml}$ of $5 \mathrm{M}$ hydrochloric acid added to a final concentration of $0.2 \mathrm{M}$ hydrochloric acid. Refractory material is unmasked with proteinase $K$ at 0.5 to $1 \mathrm{mg} / \mathrm{ml}$ (ca 20 units/mg protein (Boehringer Mannheim, UK)) in $0.01 \mathrm{M}$ phosphate in $0.15 \mathrm{M}$ sodium chloride, $\mathrm{pH} 7.4$ (PBS), for 10 to 15 minutes at $37^{\circ} \mathrm{C}^{2}$

3 After digestion, wash sections thoroughly in PBS and dry at $37^{\circ} \mathrm{C}$ (five to 15 minutes).

4 Aliquots $(9 \mu \mathrm{l})$ of hybridisation mix containing $10 \mathrm{ng}$ of appropriate biotinylated probe are added to each well on multispot slides, covered with $14 \mathrm{~mm}$ diameter coverslips, and the slides placed in a moist, sealed Terasaki plate. Hybridisation mix consists of $50 \%$ formamide (Sigma, UK), 5\% dextran sulphate (BDH, UK), $2 \times$ SSC, $0.1 \mathrm{mM}$ edetic acid, $0.5 \mu \mathrm{g}$ sheared salmon sperm DNA, and $0.05 \mathrm{mM}$ Trishydrochloric acid, $\mathrm{pH} 7 \cdot 3 ; 1 \times \mathrm{SSC}=0.15 \mathrm{M}$ sodium chloride, $0.015 \mathrm{M}$ sodium citrate. ${ }^{3}$

5 Denature at $95^{\circ} \mathrm{C}$ for 15 minutes on a solid stainless steel plate in a hot air oven and hybridise at $42^{\circ} \mathrm{C}$ for two hours.

6 Wash slides at low stringency in three changes of $4 \times \mathrm{SSC}$ at $22^{\circ} \mathrm{C}$ (five minutes each change). If high stringency washing is required for specific HPV typing rather than human gene detection, the $4 \times$ SSC washes are followed by two washes in $45 \%$ formamide in $1 \times \mathrm{SSC}$ at $37^{\circ} \mathrm{C}, \mathrm{pH} \mathrm{7.2}(10$ minutes each wash $),{ }^{4}$ and $4 \times \mathrm{SSC}$ at $22^{\circ} \mathrm{C}$ for five minutes. After these 


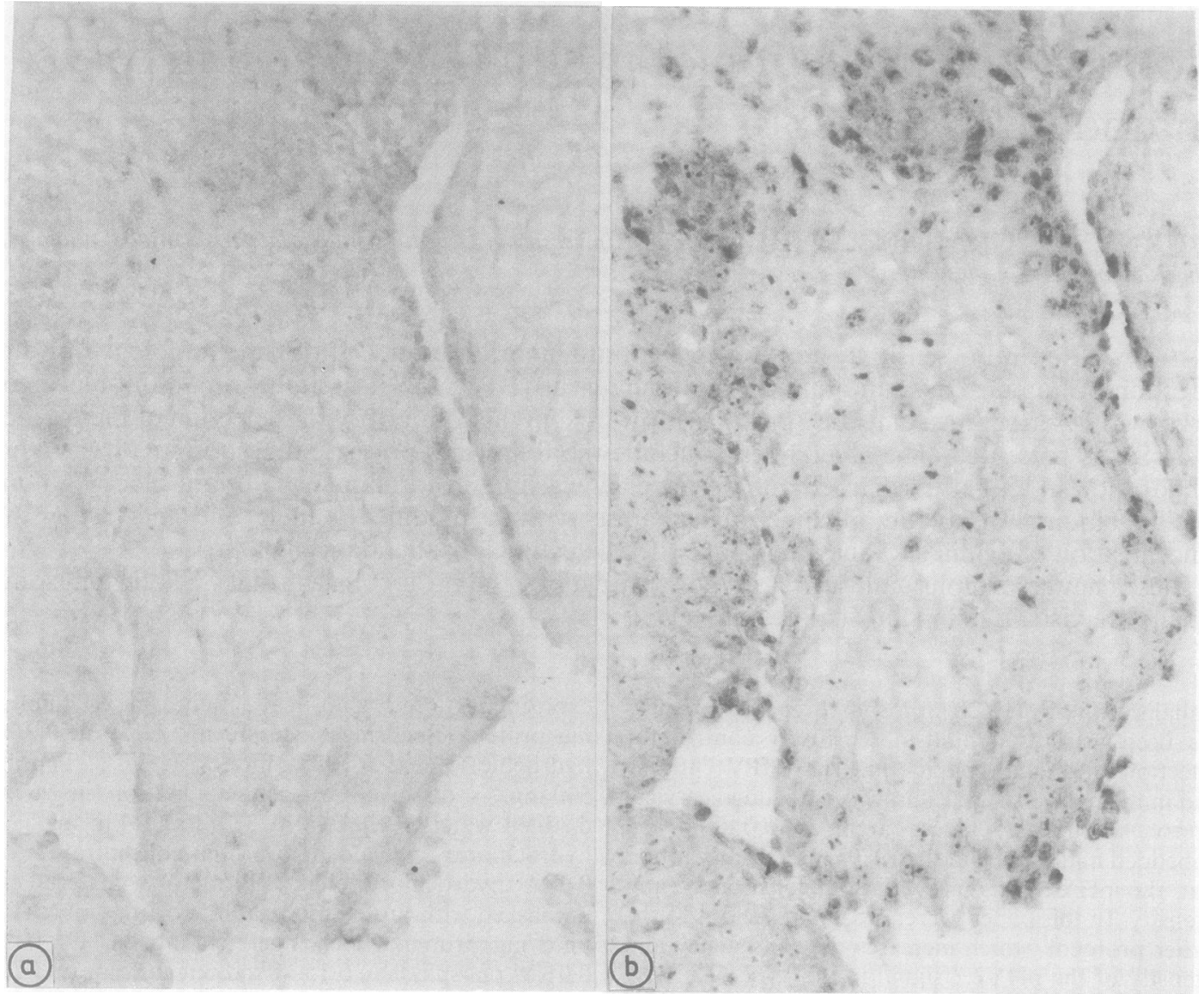

Fig la Detection of autosomal "Y sequences" with old protocol in archival cervical biopsy specimen. (Not counterstained). Nuclei are just visible at this low magnification.

Fig lb Parallel section to la but "Y sequences" detected in situ by new protocol. (Not counterstained). "Y sequences" are clearly evident in nuclei, at identical magnification.

washes, soak in blocking agent TBT (0.01 M Trishydrochloric acid, $0 \cdot 15 \mathrm{M}$ sodium chloride $(\mathrm{pH} 7 \cdot 5)$ ) containing 0.25\% (w/v) bovine serum albumin (Sigma UK; No. A7906) and 0.05\% Triton X $100(v / v)$ at $22^{\circ} \mathrm{C}$ for 10 minutes.

7 Incubate sections at $22^{\circ} \mathrm{C}$ for 30 minutes with modified avidin alkaline phosphatase conjugate (Dako) diluted in TBT. Dilutions of $1 / 25$ and $1 / 200$ are satisfactory for low and high abundance nucleic acid detection, respectively.

8 Remove unbound conjugate by washing twice for five minutes in $0.01 \mathrm{M}$ Tris-hydrochloric acid, $0.15 \mathrm{M}$ sodium chloride (pH 9.5) and incubate for five to 30 minutes in substrate consisting of nitroblue tetrazolium (NBT) and 5-bromo-4-chloro-3-indolylphosphate (BCIP). ${ }^{5}$ In practice, the NBT-BCIP substrate/buffer is made up as follows. (i) NBT (10 mg) (Sigma; N6876) is weighed into an Eppendorf tube. Dissolve in $0.2 \mathrm{ml}$ dimethylformamide and add $1 \mathrm{ml}$ of substrate buffer $(0 \cdot 1 \mathrm{M}$ Trishydrochloric acid, $0.1 \mathrm{M}$ sodium chloride, and $0.005 \mathrm{M}$ magnesium chloride, $\mathrm{pH} 9.5$ ). Transfer to a larger vessel containing $30 \mathrm{ml}$ of substrate buffer at $37^{\circ} \mathrm{C}$.

(ii) Weigh out $5 \mathrm{mg}$ of BCIP into a glass tube and dissolve in $0.2 \mathrm{ml}$ of dimethylformamide.

(iii) The BCIP solution is added in drops to the NBT solution and stirred. This final substrate mix is stored in $5 \mathrm{ml}$ aliquots at $-20^{\circ} \mathrm{C}$ until required.

9 A signal is evident in one to two minutes when HPV copy number is high. Terminate reaction by washing for five minutes in tap water and immersing for five minutes in $10 \%$ formalin containing $0 \cdot 15 \mathrm{M}$ sodium chloride. The final preparations are rinsed in 
distilled water, counterstained with pyronin, light haematoxylin or light green if required, and mounted in glycerine jelly or crystal/Mount (Biomeda, USA). This last may be postmounted in De Pex (RA Lamb, UK).

\section{Results}

Results with the old ${ }^{1}$ and present procedure are illustrated in figs $1 a$ and $b$.

\section{Discussion}

Five principal modifications to the original method have been described. Firstly, nucleic acids are unmasked by pepsin/hydrochloric acid or proteinase $\mathrm{K} / \mathrm{PBS}$ at $37^{\circ} \mathrm{C}$. Secondly, the ethanol dehydration step before in situ probing has been amended. Thirdly, the stringency washing stage has been improved. Fourthly, a different blocking and washing buffer has been introduced which increases the sensitivity and simplifies the procedure. Fifthly, avidin-alkaline phosphatase conjugates have been used at different dilutions. These modifications give the most consistent and sensitive results for human papilloma virus (HPV) detection by non-isotopic in situ hybridisation (NISH).

With pepsin/hydrochloric acid, blue nucleic acid signals are visualised against an essentially clear background. Proteinase $\mathrm{K}$ not only obtains viral nucleic acid signals but also enhances greatly the autosomal Y signal (fig lb). This may be due to its greater effectiveness in digesting native proteins. It also tends to induce a pale pink cellular background with viral probes, seldom seen after pepsin/hydrochloric acid treatment.
Interestingly, the autosomal $\mathrm{Y}$ signal is lost after high stringency washings. The $\mathrm{Y}$ signal from $\mathrm{Y}$ bodies in sections of male tonsil withstands such treatment (unpublished observation). This finding suggests that autosomal $Y$ repeat sequences in female cells are only weakly homologous to repeat sequences in the $\mathrm{Y}$ body of male cells, or that the stringency conditions in NISH are not entirely similar to standard nucleic acid analytical procedures. Further studies on this phenomenon are clearly necessary.

This work was supported by the Cancer Research Campaign.

\section{References}

1 Burns J, Graham AK, Frank C, Fleming KA, Evans MP, McGee JO'D. Detection of low copy human papilloma virus DNA and mRNA in routine paraffin sections of cervix by non isotopic in situ hybridization. J Clin Pathol 1987;40:858-64.

2 Ferguson DJP, Harrison D, Burns J, Jonasson JA, McGee JO'D. Chromosomal localization of genes by scanning electron microscopy using in situ hybridization with biotinylated probes: Y chromosome repetitive sequences. Histochem J 1986;18: 266-70.

3 Chan VT-W, Fleming KA, McGee JO'D. Detection of subpicogram quantities of specific DNA sequences on blot hybridization with biotinylated probes. Nucleic Acids Res 1985;13:8083-91.

4 Henke R-P, Milde-Lengosch K, Loning T, Kopping HS. Human papilloma virus type 13 and focal epithelial hyperplasia of the oral mucosa: DNA hybridization on paraffin-embedded specimens. Virchows Arch A 1987;411:193-8.

5 Chan VT-W, Fleming KA, McGee JO'D. Detection of subpicogram quantities of specific DNA sequences on blot hybridization with biotynylated probes. Nucleic Acids Res 1985;13:8083-91.

Requests for reprints to: Professor J O'D McGee, Nuffield Department of Pathology, John Radcliffe Hospital, Level 1, Headington, Oxford OX3 9DU, England. 
Notices

\section{Mucins in Histopathology}

\section{ACP Course: Wednesday, 24 May 1989 \\ Department of Pathology, University of Leeds}

Programme includes: Mucus glycoproteins-structural/functional relationships and biochemical/histochemical correlations. Critical review of histochemical techniques for the demonstration of epithelial glycoproteins. Lectins: structure, functions, and uses. Mucins in the gastrointestinal tract. Mucins in the respiratory tract. Mucins in the genitourinary tract. Mucins in the breast. Mucus antigens and cancer.

Course Fee: $£ 25.00$ (to include refreshments and lunch)

Apply to Dr M Wells, Department of Pathology, University of Leeds, Leeds LS2 9JT.

\section{National Heart and Lung Institute}

\section{Course in Lung Pathology 12-15 June 1989}

A course of lectures, hands-on microscopy sessions, and a slide seminar will be held at the National Heart and Lung Institute, Brompton Hospital, London.

Lecturers will include: B J Addis, P J Cole, B Corrin, P da Costa, B Fox, A R Gills, M Griffiths, P K Jeffery, M N Sheppard, S Stewart and C A Wagenvoort.

Programme and application forms available from: Postgraduate Centre, National Heart and Lung Institute, Dovehouse Street, London SW3 6LY. (01) 3518172.

\section{Fourth Annual Meeting Clinical Applications of Cytometry

\author{
Charleston, South Carolina, USA \\ September 13-16, 1989
}

Four symposia will cover the topics: transplantation; image analysis; quantitation of immunofluorescence and intracellular probing; and leukaemia/lymphoma immunophenotyping.

Related poster sessions and workshops will also be held.

For detailed information regarding the programme, advance registration, and submission of abstracts write to: Mariano La Via, Clinical Applications of Cytometry, P.O. Box 39778, Charleston, South Carolina 29407, USA.

\section{External Quality Assessment in Histopathology and Cytopathology}

External Quality Assessment is of increasing importance in histopathology and cytology. With the advent of the cytology proficiency testing scheme and the need to control quality of the newly implemented breast cancer screening, the Royal College of Pathologists and the Association of Clinical Pathologists are presenting a special one day symposium at St Bartholomew's Hospital, London EC1, on Monday April 24, 1989. Fee $£ 40.00$ including buffet lunch.

Further details from: Professor G Slavin, Department of Histopathology, St Bartholomew's Hospital, West Smithfield, London EC1.

\section{ACP Locum Bureau}

The Association of Clinical Pathologists runs a locum bureau for consultant pathologists.

Applicants with the MRC Path who would like to do locums and anyone requiring a locum should contact $\mathrm{Dr}$ DH Orrell, Department of Pathology, Royal Lancaster Infirmary, Ashton Road, Lancaster LA1 4RP.

\section{Corrections}

The references to the paper by Burns, Graham, and McGee were incorrect at time of press (J Clin Pathol 1988;41:897-99) and should be as follows:

\section{References}

1 Burns J, Graham AK, Frank C, Fleming KA, Evans MP, McGee JO'D. Detection of low copy human papilloma virus DNA and mRNA in routine paraffin sections of cervix by non isotopic in situ hybridization. J Clin Pathol 1987;40:858-64.

2 Syr Jonen S, Syr Jonen K. An improved in situ DHA hybridization protocol for detection of human papillomovirus (HPV) DNA sequences in paraffin-embedded biopsies. $J$ Virol Methods 1986;14:293-304.

3 Ferguson DJP, Harrison D, Burns J, Jonasson JA, McGee JO'D. Chromosomal localization of genes by scanning electron microscopy using in situ hybridization with biotinylated probes: $\mathrm{Y}$ chromosome repetitive sequences. Histochem J 1986;18:266-70.

4 Henke R-P, Milde-Lengosch K, Loning T, Kopping HS. Human papillomovirus type 13 and local epithelial hyperplasia of the oral mucosa: DNA hybridization on paraffinembedded specimens. Virchows Arch A 1987;411:193-8.

5 Chan VT-W, Fleming KA, McGee JO'D. Detection of subpicogram quantities of specific DNA sequences on blot hybridization with biotinylated probes. Nucleic Acids Res 1985;13:8083-91.

An error was inadvertently made to the title of the paper by Dr Savltzipori (J Clin Pathol 1988;41:1099-103). It should have read: Cerebral involvement associated with Escherichia coli 0157: H7 in humans and gnotobiotic piglets.

Broadsheet 120, January 1989: Folio 7 of the above broadsheet: (Guide to Diagnosis of inborn errors of metabolism in district general hospitals, has been reprinted owing to a series of printing errors (enclosed with this issue). 